\title{
A STUDY OF ASSOCIATION OF SEX HORMONES WITH INSULIN RESISTANCE AND OBESITY FOR DIABETES MELLITUS RISK IN ADULT WOMEN
}

\author{
Suganthy $K^{1}$, Mohanty P. K², Jeyakumar $M^{3}$, Hariharan $A^{4}$, Lakshmi Prabha $S^{5}$
}

${ }^{1}$ Associate Professor, Department of Biochemistry, Velammal Medical College Hospital Research Institute, Madurai.

2 Professor, Department of Biochemistry, Velammal Medical College Hospital Research Institute, Madurai.

${ }^{3}$ Assistant Professor, Department of Biochemistry, Velammal Medical College Hospital Research Institute, Madurai.

${ }^{4}$ Assistant Professor, Department of Biochemistry, Velammal Medical College Hospital Research Institute, Madurai.

${ }_{5}^{5}$ Associate Professor, Department of Biochemistry, Vinayaka Missions Medical College Hospital and Research Institute, Puducherry.

\section{ABSTRACT}

\section{BACKGROUND}

Sex hormones have a great impact on energy metabolism, body composition, vascular function and inflammatory responses and insulin resistance. Ovarian hormones influence insulin sensitivity across the lifespan of women. DM prevalence also affects women's health across the life stages causing the second highest mortality in South Asians. DM has polyfactorial aetiological differences between males and females. There is need of search of sex/gender specific risk factors of DM in middle aged women. Therefore, this study is undertaken to analyse the association of sex hormones with insulin resistance, obesity and lipid profile thereby to assess the DM risk.

\section{MATERIALS AND METHODS}

A cross-sectional study was done on 120 volunteered eumenorrheic women of age between 20 - 40 years. Serum estradiol, testosterone, steroid hormone-binding globulin, dehydroepiandrosterone, insulin, fasting blood glucose and lipid profile assayed by standard biochemical methods. Insulin resistance was calculated using HOMA-IR formulae. Data obtained were analysed with a set statistical significance at $\mathrm{p}<0.05$.

\section{RESULTS}

120 adult women with normal and regular menstrual cycle of range $3-7 / 28$ - 35 days were studied. The women had a mean age of $29.05 \pm 5.8$ years and were categorised into Group I (20 - 30) and Group II (31 - 40 years). The mean of sex hormone profile was in normal range. Mean BMI was $22.55 \mathrm{~kg} / \mathrm{m}^{2}$. Estradiol, testosterone and DHEA showed no significant association with HOMA-IR. SHBG showed a significant positive association with FBG, Insulin, HOMA-IR and negative with BMI. Mean Triglyceride, FBG, Insulin and IR increased in Group II was significant with $\mathrm{p}<0.05$.

\section{CONCLUSION}

Androgen level influences dyslipidaemia irrespective of the age in women. SHBG is positively associated with hyperinsulinaemia, IR and have negative association with BMI proposing that IR is not always dependent on obesity status in women. The interplay of SHBG through its impact on testosterone and estradiol levels to influence the IR has to be further studied to consider sex hormones as an independent age or gender specific DM risk marker.

\section{KEYWORDS}

Diabetes Mellitus, Dehydroepiandrosterone, Estradiol, Steroid Hormone-Binding Globulin, Testosterone, Fasting Blood Glucose, Insulin Resistance.

HOW TO CITE THIS ARTICLE: Suganthy K, Mohanty PK, Jeyakumar M, et al. A study of association of sex hormones with insulin resistance and obesity for diabetes mellitus risk in adult women. J. Evolution Med. Dent. Sci. 2017;6(73):5205-5210, DOI: $10.14260 /$ Jemds $/ 2017 / 1131$

\section{BACKGROUND}

Globally, the prevalence of diabetes in woman is increasing at an alarming rate. The women with Diabetes Mellitus (DM) stand for the second highest mortality in South Asians.(1) Diabetes affects women's health across the life stages and it is a global health issue.(2) The balanced proportion between oestrogens and androgens play an important role in

Financial or Other, Competing Interest: None.

Submission 31-07-2017, Peer Review 27-08-2017,

Acceptance 01-09-2017, Published 11-09-2017.

Corresponding Author:

Suganthy K,

Associate Professor,

Department of Biochemistry,

Velammal Medical College Hospital Research Institute,

Madurai-Tutcorin Ring Road, Anuppanadi, Madurai-625009.

E-mail:drksuganthy@gmail.com

DOI: $10.14260 /$ jemds $/ 2017 / 1131$ maintenance of energy metabolism and body composition added to the sexual function. Also, the bidirectional modulation of glucose and lipid homeostasis by sex hormones and their receptor activation in central and peripheral targets in both sexes are influenced by oestrogens and androgens. Overall, studies have shown higher testosterone levels in women and lower levels in men are related to incident diabetes. The major risk factors contributing to diabetes are biochemical, environmental, sedentary lifestyle, socioeconomic status and genetic factors. All of them together or independently are responsible for the development of the DM.(3) Besides, certain studies show Impaired Glucose Tolerance (IGT) is more common in females than males independent of age.(4)

The literature to date have shown increased fasting insulin and Fasting Blood Glucose (FBG) levels in postmenopausal compared with premenopausal women, that 
implies Insulin Resistance (IR) worsen with the menopause.(2)

In a normal population also the aging process is associated with a gradual increase in obesity, IR and $\beta$-cell decompensation leading to DM development.(5) Few studies have prospectively examined endogenous sex hormones as predictors of type 2 diabetes in women.(6) Therefore, the relationship of sex hormones producing metabolic and endocrine imbalances associated with lipid profile and IR will contribute to more awareness in terms of sex- and genderspecific risk factors.

\section{Objectives}

To determine the level of serum estradiol, testosterone, sex hormone-binding globulin, dehydroepiandrosterone and lipid profile in eumenorrheic adult women. To determine the level of fasting blood glucose, serum insulin and insulin resistance in eumenorrheic adult women. To analyse the association of sex hormones with insulin resistance, obesity and lipid profile to assess their diabetes mellitus risk.

\section{MATERIALS AND METHODS}

It is a cross-sectional study on eumenorrheic females having a normal monthly menstrual cycle of at least nine menstrual cycles in the preceding 12 months. A total of 352 participants were initially studied for the research. Finally, for the convenience of this study 120 female subjects who met the inclusion criteria were studied. All participants gave written informed consent and completed all testing procedures in accordance with the Institutional Ethical Board guidelines. Apparently, 120 healthy women of 20 - 40 years of age being free of known metabolic disease such as DM, hyperlipidaemia, hypertension, thyroid disorder, polycystic ovary syndrome and cardiovascular disease who met the inclusion criteria were selected for this study.

\section{Exclusion Criteria}

Menopausal women, amenorrhoeic women, pregnant, lactating women, infertile women or taking medications that would affect blood pressure, carbohydrate or lipid metabolism, oral contraceptives.

All the study subjects' physical, anthropometric measurements, detailed clinical history, menstrual history and family history, general, clinical and gynaecological examination was recorded. The blood specimens were obtained in the morning of 2 - $5^{\text {th }}$ day of a spontaneous menstrual cycle after overnight fasting. Blood sample centrifuged and serum separation was used for the analysis of biochemical parameters given below-

1. Serum Estradiol,(7) Testosterone,(8) Insulin,(9) SHBG,(10) DHEA(11)- Enzyme immunoassay for all samples were performed using the DRG Diagnostics kit by plotting the standard curve with an ELISA reader.

2. Other parameters like Serum Total Cholesterol (TC) (CHOD-PAP Method), Triglyceride (TG) (GPO-PAP Method), HDL-Cholesterol (Precipitating Reagent Method), FBG (Glucose Oxidase-Peroxidase method), Total protein (Biuret method) and Albumin (Bromocresol green method) were analysed using kits obtained from Primal Health Care in semi-auto analyser.

3. Calculated parameters: Body Mass Index (BMI) $=$ Weight (kg)/Height $\left(\mathrm{m}^{2}\right)$.
Homeostasis Model Assessment Insulin Resistance Score (HOMA-IR score) $=$ fasting glucose $(\mathrm{mmol} / \mathrm{L}) \times$ fasting insulin $(\mu \mathrm{IU} / \mathrm{mL}) / 22.5$.

All quantitative data obtained were statistically analysed and presented as mean \pm SD. Student's ' $t$ ' test and Pearson correlation analysis was performed in MS Excel software with a set statistical significance at $\mathrm{p}<0.05$.

\section{RESULTS}

The mean age of the eumenorrheic women participated in this study was $29.05 \pm 5.8$ years. Their blood pressure and other basic parameters were within normal limits. The biochemical analysis of serum Estradiol (E2), Dehydroepiandrosterone (DHEA), Steroid Hormone Binding Globulin (SHBG), Testosterone (T), Insulin, FBG and lipid profile were observed to be in normal limits (Table 1).

\begin{tabular}{|c|c|c|}
\hline $\begin{array}{c}\text { Parameters } \\
\text { (Normal Reference } \\
\text { Range) }\end{array}$ & $\begin{array}{c}\text { Study } \\
\text { Subjects } \\
\text { (N = 120) } \\
\text { Mean }\end{array}$ & $\begin{array}{c}\text { Study Subjects } \\
\text { (N = 120) } \\
\text { Standard } \\
\text { Deviation }\end{array}$ \\
\hline Age $(20-40 \mathrm{yrs}$ ) & 29.05 & 5.8 \\
\hline Pulse Rate (per min.) & 76.4 & 4.07 \\
\hline Systolic BP $(\mathrm{mmHg})$ & 112.3 & 5.5 \\
\hline Diastolic BP $(\mathrm{mmHg})$ & 79.3 & 4.7 \\
\hline BMI $\left(<23 \mathrm{~kg} / \mathrm{m}^{2}\right)$ & 22.55 & 2.4 \\
\hline Estradiol $(13-191 \mathrm{pg} / \mathrm{mL})$ & 62.55 & 38.7 \\
\hline $\begin{array}{c}\text { Testosterone } \\
(0.26-1.22 \mathrm{ng} / \mathrm{mL})\end{array}$ & 1.08 & 0.8 \\
\hline DHEA $(1.3-9.8 \mathrm{ng} / \mathrm{mL})$ & 11.3 & 7.4 \\
\hline SHBG $(15-120 \mathrm{nmol} / \mathrm{L})$ & 106.4 & 48.07 \\
\hline $\begin{array}{c}\text { T. Cholesterol } \\
(150-200 \mathrm{mg} / \mathrm{dL})\end{array}$ & 177.8 & 26.27 \\
\hline Triglyceride $(<150 \mathrm{mg} / \mathrm{dL})$ & 147.65 & 28.4 \\
\hline HDL-C $(45-65 \mathrm{mg} / \mathrm{dL})$ & 48.5 & 3.8 \\
\hline LDL-C $(<100 \mathrm{mg} / \mathrm{dL})$ & 99.8 & 25.03 \\
\hline FBG $(70-110 \mathrm{mg} / \mathrm{dL})$ & 80.2 & 18.12 \\
\hline Insulin $(2-25 \mu \mathrm{IU} / \mathrm{mL})$ & 13.48 & 9.9 \\
\hline HOMA-IR $(<2.5)$ & 2.6 & 1.8 \\
\hline $\begin{array}{c}\text { Table 1. Characteristics of Baseline, Sex Hormones, } \\
\text { Insulin and Lipid Profile Parameters of Study Subjects }\end{array}$ \\
\hline
\end{tabular}

The adult women participated in this study were categorised to Group I (20 - 30 years) and Group II (31 - 40 years).

\begin{tabular}{|c|c|c|c|}
\hline Group & $\begin{array}{c}\text { Total } \\
\text { Women } \\
\text { (N= 120) }\end{array}$ & $\begin{array}{c}\text { Age (Years) } \\
\text { Mean } \pm \text { SD }\end{array}$ & $\begin{array}{c}\text { Menstrual } \\
\text { Cycle } \\
\text { (Days) Mean }\end{array}$ \\
\hline $\begin{array}{c}\text { Group I } \\
(20-30 \text { years })\end{array}$ & 61 & $24.0 \pm 2.5$ & $4 / 30$ \\
\hline $\begin{array}{c}\text { Group II } \\
(31-40 \text { years })\end{array}$ & 59 & $34.2 \pm 3.06$ & $4 / 28$ \\
\hline \multicolumn{4}{|c|}{ Table 2. Categorisation of Study Subjects based on Age } \\
\hline
\end{tabular}

In the categorised groups, mean BMI and other basic parameters were in normal range in categorised groups. Although, mean of sex hormone profile found to be different in both the groups, but were not statistically significant. The mean serum triglyceride level in Group II (31 - 40 years) was $153.03 \pm 37.3 \mathrm{mg} / \mathrm{dL}$ observed to be increased and significant $(\mathrm{p}=0.02)$. 


\begin{tabular}{|c|c|c|c|}
\hline Parameters & \begin{tabular}{|c|} 
Group I \\
$(\mathrm{N}=61)$ \\
$20-30$ Years \\
Mean \pm SD
\end{tabular} & $\begin{array}{c}\text { GROUP II } \\
(\mathrm{N}=59) \\
31-40 \text { years } \\
\text { Mean } \pm \text { SD }\end{array}$ & $\begin{array}{c}\text { t-value } \\
\text { (p-value) }\end{array}$ \\
\hline Age & $24.0 \pm 2.5$ & $34.2 \pm 3.06$ & $\begin{array}{c}20.02 \\
(0.0001) *\end{array}$ \\
\hline BMI (kg/ & 22.8 & 22.4 & 1.08 \\
\hline Estr: & 58.75 & 66.4 & 1.08 \\
\hline Testos & 1.0 & 1.4 & 1.4 \\
\hline & 12.0 & $10.6 \pm 7.9$ & 1.06 \\
\hline & 8.07 & $108.7 \pm 67.6$ & 1.14 \\
\hline T. Chole & 175.5 & $180.27 \pm 27.7$ & 0.996 \\
\hline Triglyce & $141.18 \pm 13.2$ & $153.03 \pm 37.3$ & 2.331 \\
\hline HDL-Cholesterol & $48.7 \pm 3.8$ & $48.4 \pm 3.9$ & 0.42 \\
\hline LDL-Cholesterol & $98.56 \pm 28.2$ & $101.25 \pm 24.7$ & $0.55(0.583)$ \\
\hline FBG & $76.48 \pm 13.3$ & $85.9 \pm 18.08$ & $3.2(0$. \\
\hline Fasting Insulin & $11.6 \pm 7.2$ & $15.4 \pm 11.9$ & $2.12(0.03)^{*}$ \\
\hline HOMA-IR & $2.22 \pm 1.5$ & $3.12 \pm 2.06$ & $2.16(0.03)^{*}$ \\
\hline \multicolumn{4}{|c|}{$\begin{array}{c}\text { Table 3. Baseline Parameters, Body Mass Index, Sex } \\
\text { Hormones, Insulin and Lipid Profile of } \\
\text { Categorised Study Subjects }\end{array}$} \\
\hline
\end{tabular}

(* p value $<0.05$ and statistically significant)

Several studies for defining cut-off values of HOMA-IR have been published, increased insulin resistance is considered of HOMA-IR $>2.5$ in accordance of Kyung-Jin Yun et al study.(12,13) Insulin resistance was increased in Group II (31 - 40 years). The mean values of serum FBG, insulin and insulin resistance level in Group II (31 - 40 years) was 85.9 $\mathrm{mg} / \mathrm{dL}(\mathrm{p}=0.001), 15.4 \mu \mathrm{IU} / \mathrm{mL}(\mathrm{p}=0.03)$ and $3.12(\mathrm{p}=$ 0.03 ) respectively and were observed to be significant.

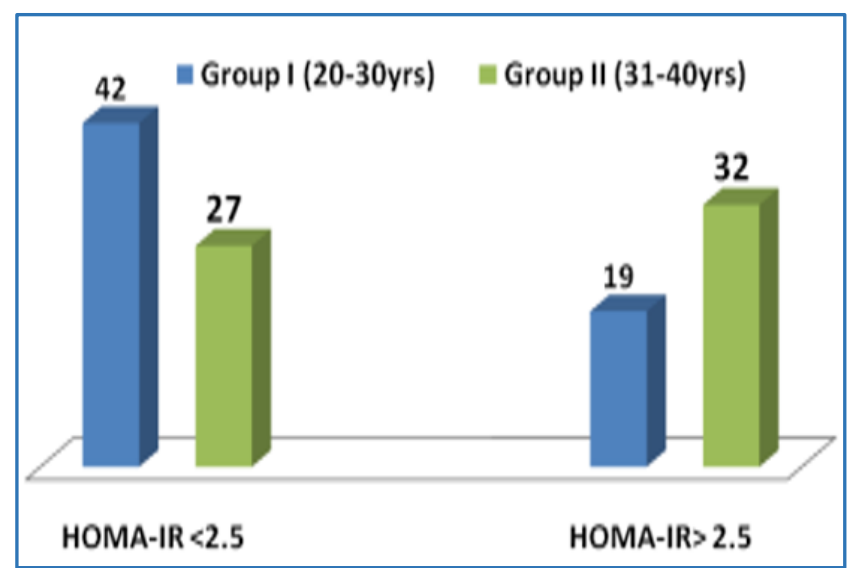

Figure 1. Distribution of Insulin Resistance (HOMA-IR > 2.5) in the Categorised Study Groups

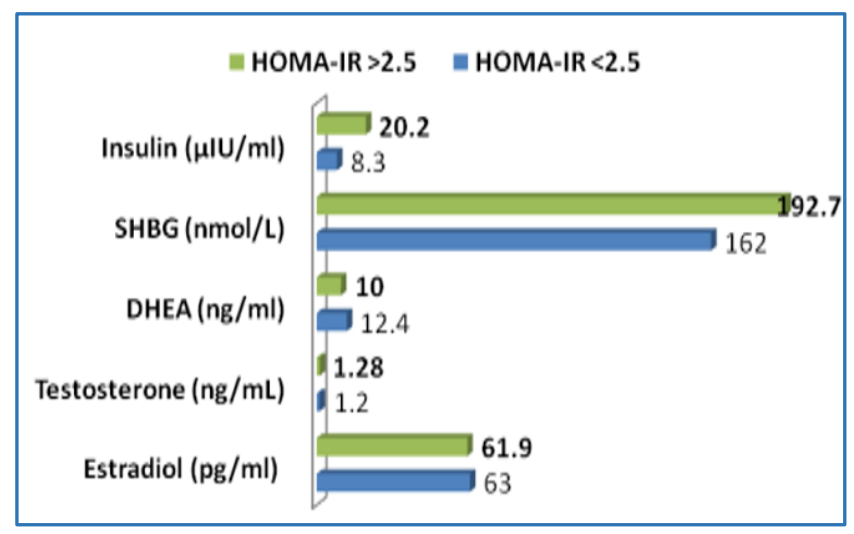

Figure 2. Mean Value of Sex Hormone

Profile Based on their Insulin Resistance Status

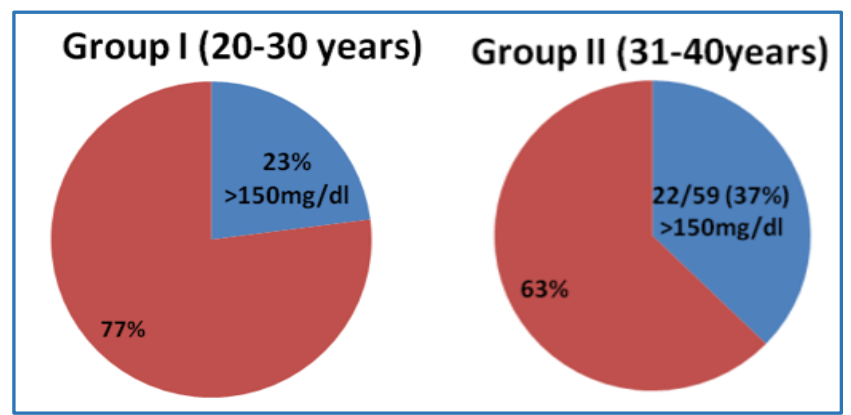

Figure 3. Distribution of Hypertriglyceridaemia (TG $>150 \mathrm{mg} / \mathrm{dL}$ ) in the Categorised Study Groups

$54.2 \%$ had increased insulin resistance and $37 \%$ of Group II had hypertriglyceridaemia. The mean value of serum Estradiol and Testosterone showed no significant change in hypertriglyceridaemic and IR $>2.5$ women. Mean value of FBG, Insulin and SHBG levels were statistically increased and DHEA was decreased in hypertriglyceridaemic and IR women.

\begin{tabular}{|c|c|c|c|c|}
\hline Parameters & $\begin{array}{c}\text { Estradiol } \\
\text { (pg/mL) } \\
\text { R-value }\end{array}$ & $\begin{array}{c}\text { Testosterone } \\
\text { (ng/mL) } \\
\text { R-value }\end{array}$ & $\begin{array}{c}\text { DHEA } \\
\text { (ng/mL) } \\
\text { R-value }\end{array}$ & $\begin{array}{c}\text { SHBG } \\
\text { (nmol/L) } \\
\text { R-value }\end{array}$ \\
\hline Age $($ Years) & 0.127 & 0.164 & $-0.197^{*}$ & -0.059 \\
\hline BMI $\left(\left(\mathrm{kg} / \mathrm{m}^{2}\right)\right.$ & -0.002 & 0.079 & 0.128 & $-0.186^{*}$ \\
\hline TC $(\mathrm{mg} / \mathrm{dL})$ & -0.013 & 0.262 & -0.141 & 0.105 \\
\hline TGL $(\mathrm{mg} / \mathrm{dL})$ & -0.06 & 0.208 & -0.06 & -0.045 \\
\hline HDL-C $(\mathrm{mg} / \mathrm{dL})$ & 0.04 & -0.114 & 0.065 & -0.003 \\
\hline LDL-C $(\mathrm{mg} / \mathrm{dL})$ & 0.007 & $0.392^{*}$ & -0.144 & 0.121 \\
\hline FBG $(\mathrm{mg} / \mathrm{dL})$ & -0.002 & 0.079 & -0.099 & $0.273^{*}$ \\
\hline $\begin{array}{c}\text { Insulin } \\
(\mu \mathrm{IU} / \mathrm{mL})\end{array}$ & 0.03 & -0.136 & -0.144 & $0.297^{*}$ \\
\hline HOMA-IR & -0.009 & -0.103 & -0.135 & $0.369^{*}$ \\
\hline
\end{tabular}

Table 4. Pearson Correlation Analysis of Sex Hormone Profile with Age, Body Mass Index, Lipid Profile, $F B G$, Insulin and IR in the Study Subjects

$\left({ }^{*} \mathrm{p}\right.$ value $<0.05$ and statistically significant, $\mathrm{r}$ - value is the Pearson correlation).

The Pearson correlation analysis showed DHEA had significant negative association with age $(r=-0.197)$. The sex hormones milieu Estradiol, DHEA and SHBG showed no significant association with lipid profile parameters. Testosterone had positive correlation with lipid profile, especially LDL-C $(r=0.392, \mathrm{p}<0.05)$ except HDL-C $(\mathrm{r}=$ 0.114 ) showed negative association. Estradiol, DHEA and Testosterone showed no statistical significant association with FBG, Insulin and Insulin Resistance. SHBG showed significant positive correlation with FBG $(r=0.273)$, Insulin $(\mathrm{r}=0.297)$ and HOMA-IR $(\mathrm{r}=0.369)$.

BMI had no significant association with Estradiol $(\mathrm{r}=$ 0.002), Testosterone $(r=0.079)$ and DHEA ( $r=0.128)$. The correlation of SHBG with BMI ( $\mathrm{r}=-0.186)$ observed to be statistically significant negative association. The women with normal range of sex hormones profile showed less prone for obesity. 


\begin{tabular}{|c|c|c|}
\hline Parameters & $\begin{array}{c}\text { Group I 20 - 30 } \\
\text { years (N = 61) } \\
\text { n (\%) }\end{array}$ & $\begin{array}{c}\text { Group II 30 - 40 } \\
\text { Years (N = 59) } \\
\text { n (\%) }\end{array}$ \\
\hline $\mathrm{BMI}>23 \mathrm{~kg} / \mathrm{m}^{2}$ & $16(26.2 \%)$ & $22(37.2 \%)$ \\
\hline $\mathrm{TC}>200 \mathrm{mg} / \mathrm{dL}$ & $7(11.4 \%)$ & $7(11.4 \%)$ \\
\hline $\mathrm{TG}>150 \mathrm{mg} / \mathrm{dL}$ & $14(22.9 \%)$ & $22(37.2 \%)$ \\
\hline $\mathrm{HDL}-\mathrm{C}<45 \mathrm{mg} / \mathrm{dL}$ & $3(4.9 \%)$ & $7(11.8 \%)$ \\
\hline $\mathrm{LDL}-\mathrm{C}>110 \mathrm{mg} / \mathrm{dL}$ & $13(21.3 \%)$ & $19(32.2 \%)$ \\
\hline $\mathrm{FBG}>110 \mathrm{mg} / \mathrm{dL}$ & $0(0 \%)$ & $4(6.7 \%)$ \\
\hline Fasting & $3(4.9 \%)$ & $2(3.3 \%)$ \\
Insulin $>30 \mu \mathrm{IU} / \mathrm{mL}$ & $2(3.2 \%)$ & $3(5 \%)$ \\
\hline $\mathrm{HOMA} \mathrm{IR}>6.4$ & $1(1.6 \%)$ & $3(5 \%)$ \\
\hline Family H/O DM & \multicolumn{2}{|c|}{ Table 5. Distribution of Diabetic } \\
\hline \multicolumn{2}{|c|}{ Risk Profile among Categorised Study Subjects } \\
\hline
\end{tabular}

$42.5 \%(51 / 120)$ women were with HOMA-IR $>2.5$ and of which $54.2 \%$ (32/59) were in Group II (31 - 40 yrs.) shown in Fig. 2. Although, $42.5 \%$ had increased IR, diabetic risk with HOMA-IR > 6.4 was present only in $4.1 \%(5 / 120)$ of adult women; $37 \%$ had increased BMI and serum triglycerides in Group II (31 - 40 yrs.); 4/59 (6.7\%) had FBG > 110 mg/dL, $3 / 59$ (5\%) had HOMA-IR > 6.4 indicating their DM risk. On the total study subjects, $3 \%(4 / 120)$ had DM risk of FBG > $110 \mathrm{mg} / \mathrm{dL}$.

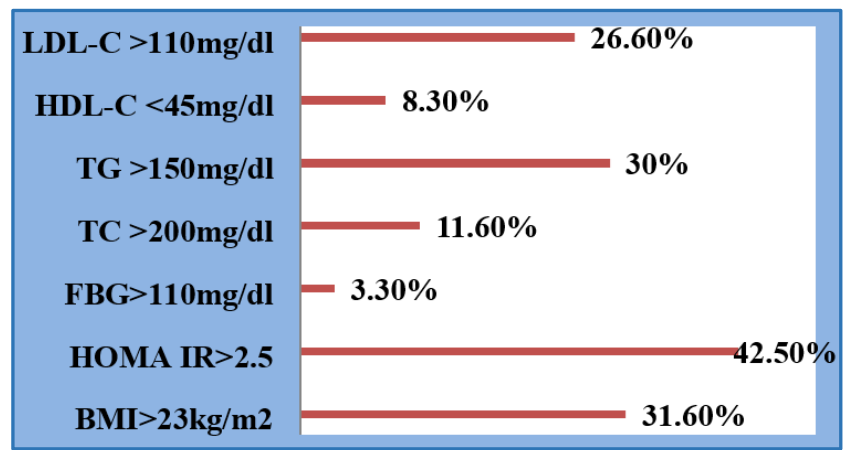

Figure 4. Distribution of Dyslipidaemia and Diabetic Risk Profile in Adult Women

\section{DISCUSSION}

The female sex hormone milieu changes from prepubertal to postmenopausal age. These hormones not only play an important role in reproduction, but also influence other systems and metabolism in the body. Insulin resistance is closely associated with cardiovascular risk factors, diabetes mellitus, dyslipidaemia and hypertension.

In this study, mean age of adult women was $29.05 \pm 5.8$ years compared to $38 \pm 7$ years in Sower et al.(14) The mean of estradiol, testosterone and lipid profile were in normal range. The adult women participated in this study were categorised into two groups based on their age as Group I (20 - 30 years, $\mathrm{N}=61)$ and Group II (31 -40 years, $\mathrm{N}=59)$.

The mean estradiol, testosterone and SHBG showed increased level and DHEA showed decreased level in Group II (31 - 40 years) and statistically not significant. Oestrogen is one of the important female sex hormones. The serum estradiol in the women ranged from $44.04-252.7 \mathrm{pg} / \mathrm{mL}$ with mean of $62.55 \pm 38.7$ (reference value $13-191 \mathrm{pg} / \mathrm{mL}$ ). E2 plays an important role in blood glucose, homeostasis may be associated with $\mathrm{DM}$ risk by its relation to insulin resistance, adiposity and inflammatory markers.(15) $17 \beta$ - estradiol levels above or below the physiological range may promote IR and type 2 diabetes. High endogenous E2 in physiological states such as puberty, luteal phase of menstrual cycle and late pregnancy are associated with insulin resistance and may involve reduced GLUT4 muscle expression.(16)

The relative importance of Testosterone (T) to women's health in reproductive years, the menopause transition and the post menopause has been a matter of speculation. Serum testosterone in Group II (mean age $34 \pm 3.06$ years) was 1.47 $\pm 1.0 \mathrm{ng} / \mathrm{mL}$ slightly increased compared to Group I. The mean age and serum testosterone of Sarantis Livadas et al study was $32.21 \pm 14.40$ and $1.36 \pm 0.47 \mathrm{nmol} / \mathrm{L}$ respectively.(5) Hypoandrogenaemia in men and hyperandrogenaemia in women are associated with increased risk of CAD, but also with visceral obesity, IR, low HDL-C and elevated TG and LDL-C.(17) High testosterone levels are associated with higher risk of type 2 diabetes in women, but with lower risk in men.(18) Therefore, at physiological levels, $\mathrm{T}$ and E2 are thought to be involved in maintaining normal insulin sensitivity. However, outside this 'physiological window' these steroids may promote insulin resistance.

DHEA is an anabolic hormone converted to DHEA-S (sulfated form) in the liver and subsequently converted to more active androgens in the adrenals and peripheral tissues including testosterone, 5-dihydrotestosterone and oestrogens. The mean DHEA was $11.3 \pm 7.4(1.3-9.8 \mathrm{ng} / \mathrm{mL})$ in the study subjects. The serum DHEA in Group II (30 - 40 years) was less compared to Group I (20 - 30 years). DHEA decline in a linear fashion with age results in deficiency of androgens and oestrogens in peripheral tissues proposed to be associated with age-related diseases of obesity and insulin resistance.(11)

SHBG a transport glycoprotein, synthesised in the liver with concentrations being regulated by the androgen/oestrogen balance, thyroid hormones and insulin. After puberty, SHBG levels decrease more rapidly in males than in females. Levels are normally stable in adults and in postmenopausal women. SHBG levels have positive associations with HDL-C concentrations and negative associations with LDL-C, oxLDL-C, triglyceride and Apo-B levels.(19) Mean SHBG $106.4 \pm 68.07 \mathrm{nmol} / \mathrm{L}$ was increased compared to Sower et al(14) study showed mean of $65.0 \pm 3.3$ nmol/L in premenopausal study subjects. SHBG concentrations predicted the development of NIDDM in women independently of glucose and insulin concentrations. ${ }^{(20)}$

In the study population, mean FBG $(80.2 \pm 18.1 \mathrm{mg} / \mathrm{dL})$ and Insulin $(13.4 \pm 9.9 \mu \mathrm{IU} / \mathrm{mL})$ were in normal limits. Mean HOMA-IR $(2.6 \pm 1.8)$ was in higher range. IR increased in Group II (31 - 40 yrs.) was statistically significant $(\mathrm{t}=2.16$, $\mathrm{p}$ $=0.01$ ). The HOMA-IR cut-off point for diagnosis of Insulin resistance $>2.5$ is valid for adults in many studies.(12,13) In our study, $42.5 \%$ (51/120) women showed increased IR and of which 54.2\% (32/59) were in Group II (31 - 40 yrs.). Although, $42.5 \%$ had increased IR, diabetic risk with HOMAIR $>6.4$ was present only in $4.1 \%(5 / 120)$ of women.

The correlation analysis of Estradiol showed no significant association with lipid parameters and insulin resistance. Estradiol was positively associated with age $(\mathrm{r}=$ 0.127), but not significant. Estradiol had positive association 
with BMI ( $\mathrm{r}=0.094, \mathrm{p}=\mathrm{NS})$ and HDL-C $(\mathrm{r}=0.129, \mathrm{p}=\mathrm{NS})$, which is accepted with the hypothesis proposed that higher HDL and lower LDL levels in premenopausal women are likely to protect them against atherosclerosis and the difference may be casually related to Estradiol levels by Kalavathi et al(21) and Jesper et al(22) study. Testosterone had positive association with age $(\mathrm{r}=0.164), \mathrm{TC}(\mathrm{r}=262), \mathrm{TG}(\mathrm{r}=$ 208), LDL-C ( $r=0.166)$ and negative association with HDL-C $(r=-0.114)$. Thus with increase of age, the $\mathrm{T}$ increases and it increases TC, TG, LDL-C and decreases HDL-C in women similar to Van Pottelbergh et al study.(23) T had no significant association with IR and BMI in this study, but $\mathrm{T}$ had significant correlation with BMI and leptin levels there exists a bidirectional relationship of $\mathrm{T}$ and insulin to reduce fat mass by improving insulin action.(24) Androgens activate the expression of $\beta$-adrenergic receptors, protein kinase $A$ and hormone sensitive lipase. As a result, $\mathrm{T}$ stimulates lipolysis and reduces fat storage in adipocytes. Androgens elicit an antiadipogenic effect in preadipocytes in vitro, whereas oestrogens elicit a proadipogenic hormone effects that are related to changes in the expression of the IGF receptor and peroxisomal proliferator-activated receptor $\gamma 2$ expression.(24) $31.6 \%(38 / 120)$ were obese with (BMI > $23 \mathrm{~kg} / \mathrm{m}^{2}$ ) with more obese women in Group II (31 - 40 years). But their mean BMI $(22.5 \pm 2.4 \mathrm{~kg} / \mathrm{m} 2)$ was in normal limits and ranged from $16.2-28.1 \mathrm{~kg} / \mathrm{m}^{2}$. BMI had no significant association with Estradiol, Testosterone and DHEA. The premenopausal women with normal sex hormones profile showed less prone for obesity.

The correlation of SHBG with BMI $(r=-0.186, \mathrm{p}<0.05)$ observed to be statistically significant negative association similar to De Pergola et al(25) in obese premenopausal women. The correlation of SHBG with carbohydrate profile showed significant and positive association namely FBG ( $\mathrm{r}=0.273$, $\mathrm{p}<$ 0.05), Insulin ( $\mathrm{r}=0.297, \mathrm{p}<0.05)$ and HOMA-IR ( $\mathrm{r}=0.369, \mathrm{p}<$ $0.05)$, whereas in vivo assessment in both pre- and postmenopausal women suggested that increased free testosterone and decreased SHBG is associated with high glucose and insulin concentration.(20,26) The correlation analysis of SHBG with TC was not significant compared to Berman et al $(r=0.3, p=0.03)$ showed significant positive association.(26) Bell RJ et al study showed a low SHBG levels detect CVS risk profile with a significant association for HDL$\mathrm{C}(\mathrm{p}<0.01)$ and TG $(\mathrm{p}<0.01)$ in both premenopausal and postmenopausal women, but not significant in this study with HDL-C ( $\mathrm{r}=-0.003, \mathrm{p}=\mathrm{NS})$ and TG $(\mathrm{r}=-0.045, \mathrm{p}=\mathrm{NS}) .{ }^{(27)}$

The correlation of DHEA with age $(r=-0.197, p<0.05)$ was negative in accordance of fact that DHEA in women declines in a linear fashion with age.(24) The pool of androgens in women decreases progressively from the age of 30 years in parallel with the decrease in serum concentration of DHEA. DHEA observed to show negative association with TC, TG, LDL-C and cholesterol ratios, FBG, Insulin and Insulin resistance and positive association with HDL-C, but statistically not significant. DHEA supplementation decreases lipid parameters and fasting plasma glucose and insulin levels by Labrie et al study.(11) In the present study DHEA showed positive association with BMI $(r=0.125, p=N S)$, but in De Pergola et al(25) study showed a statistically significant negative association ( $\mathrm{r}=-0.376, \mathrm{p}<0.05)$ in obese premenopausal women.
Although, Estradiol showed negative association with lipid parameters, Testosterone was positively associated with dyslipidaemia and increased insulin resistance, serum SHBG observed to have statistically significant ( $p<0.05)$ association with hypertriglyceridaemia and IR. The mean Estradiol $(61.9 \pm 36.5 \mathrm{pg} / \mathrm{mL})$ observed in premenopausal women with IR $>2.5$ was not statistically significant on comparison to HOMA-IR $<2.5$ women, but Estradiol levels were elevated among men and postmenopausal women with diabetes compared with controls $(p=.007)$ by Ding EL et al study.(18) SHBG in clinical practice can be a useful diagnostic tool for correct interpretation of testosterone and estradiol serum concentration, investigating androgen-oestrogen balance and evaluating insulin resistance and cardiovascular risk. SHBG concentrations are low and correlate negatively with both BMI and fasting insulin levels. Because of the inhibitory effect of both insulin and insulin-like growth factor-1 on SHBG secretion by Hep G2 cells in vitro, it has been proposed that SHBG levels could be a marker of insulin resistance and/or hyperinsulinism in humans. Therefore, there is definite dyslipidaemia associated cardiovascular and diabetic risk even if their BMI is $<23 \mathrm{~kg} / \mathrm{m}^{2}$ and with normal physiological range of serum oestrogen and androgen levels in adult women.

\section{CONCLUSION}

120 premenopausal women with normal and regular menstrual cycle of range 3 - 7/ 28 - 35 days constitute the study population. The mean of sex hormone, lipid profile and BMI were in normal range and observed to be not statistically significant difference in age wise categorised premenopausal women. Serum Estradiol, Testosterone and DHEA showed no significant association with body mass index. Hypercholesterolaemia (11.6\%), Hypertriglyceridaemia (30\%) and increased HOMA-IR (42.5\%) observed in the study females.

The adult women are definitely at risk of dyslipidaemia, obesity, diabetes and cardiovascular diseases as the age advances to menopause transition. Testosterone increase and DHEA decrease with age was not observed to be at statistical significant level in this study population. The correlation of estradiol, DHEA, SHBG with lipid parameters was not significantly made out in this study. Testosterone showed a significant positive association with LDL-C and negative association with HDL-C. Thus, in premenopausal period androgen levels even in normal range influences dyslipidaemia irrespective of their age. SHBG is positively associated with hyperinsulinaemia, HOMA-IR and have negative association with BMI proposing that IR is not always dependent on obesity status of women.

Mean TG, FBG, Fasting Insulin and HOMA-IR were increased in Group II (31 - 40 years) compared to Group I (20 - 30 years) and statistically significant with $p<0.05$. Sex hormone-binding globulin gene polymorphisms may influence IR and cause a high risk of DM through its impact on testosterone and estradiol levels can be further studied. Thus, the interplay between sex steroids and insulin resistance has to be studied further to consider their implications for prediabetes risk. 


\section{REFERENCES}

[1] Bajaj S, Jawad F, Islam N, et al. South Asian women with diabetes: psychosocial challenges and management: consensus statement. Indian J Endocr Metab 2013;17(4):548-62.

[2] Aufaira shaker nsaif MSC. Study the effect of sex hormones in diabetic women. Iraqi J Comm Med 2014;1:18-20.

[3] Kautzky-Willer A, Harreiter J, Pacini G. Sex and gender differences in risk, pathophysiology and complications of type 2 diabetes mellitus. Endocr Rev 2016;37(3):278-316.

[4] Huang Y, Cai X, Chen P, et al. Associations of prediabetes with all-cause and cardiovascular mortality: a meta-analysis. Ann Med 2014;46(8):68492.

[5] Livadas S, Kollias A, Panidis D, et al. Diverse impacts of aging on insulin resistance in lean and obese women with polycystic ovary syndrome: evidence from 1345 women with the syndrome. Eur J Endocrinol 2014;171(3):301-9.

[6] Ding EL, Song Y, Manson JE, et al. Plasma sex steroid hormones and risk of developing type 2 diabetes in women: a prospective study. Diabetologia 2007;50(10):2076-84.

[7] Ractiff WA, Carter GD, Dowsett M, et al. Oestradiol assays: application and guidelines for the provision of a clinical biochemistry service. Ann Clin Biochem 1988;25(Pt 5):466-83.

[8] Tietz NW. Textbook of clinical Biochemistry. Philadelphia, WB Saunders; 1986:pp 1919.

[9] Robbins DC, Andersen L, Bowsher R, et al. Report of the American diabetes association's task force on standardization of the insulin assay. Diabetes 1996;45(2):242-56.

[10] Von Schoultz B, Carlstrom K. On the regulation of sex hormone binding globulin-a challenge of an old dogma and outlines of an alternative mechanism. J Steroid Biochem 1989;32(2):327-34.

[11] Labrie F, Luu-The V, Belanger A, et al. Is dehydroepiandrosterone a hormone? J Endocrinol 2005;187(2):169-96.

[12] Yun KJ, Han K, Kim MK, et al. Insulin resistance distribution and cut-off value in koreans from the 2008-2010 korean national health and nutrition examination survey. PLoS One 2016;11(4):e0154593.

[13] Keskin M, Kurtoglu S, Kendirci M, et al. Homeostasis model assessment is more reliable than the fasting glucose/insulin ratio and quantitative insulin sensitivity check index for assessing insulin resistence among obese children and adolescents. Pediatrics 2005;115(4:e500-3.
[14] Sowers MFR, Zheng H, McConnell D, et al. Testosterone, sex hormone-binding globulin and free androgen index among adult women: chronological and ovarian aging. Hum Reprod 2009;24(9):2276-85.

[15] Nadal A, Alonso-Magdalena P, Soriano S, et al. The pancreatic beta-cell as a target of estrogens and xenoestrogens: implications for blood glucose homeostasis and diabetes. Mol Cell Endocrinol 2009;304(1-2):63-8.

[16] Barros RP, Morani A, Moriscot A, et al. Insulin resistance of pregnancy involves estrogen-induced repression of muscle GLUT4. Mol Cell Endocrinol 2008;295(1-2):24-31.

[17] Eckardstein $\mathrm{A}, \mathrm{Wu}$ FC. Testosterone and atherosclerosis. Growth Horm IGF Res 2003;13 Suppl A:S72-84.

[18] Ding EL, Song Y, Malik VS, et al. Sex differences of endogenous sex hormones and risk of type 2 diabetes: a systematic review and meta-analysis. JAMA 2006;295(11):1288-99.

[19] Sowers MFR, Randolph J, Jannausch M, et al. Levels of sex steroid and CVD measures in premenopausal and hormone-treated women at mid-life: implications for the "timing hypothesis. Arch Intern Med 2008;168(19):2146-53.

[20] Haffner SM, Valdez RA, Morales PA, et al. Decreased sex hormone-binding globulin predicts noninsulindependent diabetes mellitus in women but not in men. J Clin Endocrinol Metab 1993;77(1):56-60.

[21] Kalavathi L, Dhruvanarayan HR, Zachariah E. Plasma estradiol and lipid profile in perimenopausal women. Indian J Physiol Pharmacol 1991;35(4):260-2.

[22] Gyllenborg J, Rasmussen SL, Heitmann BL, et al. Cardiovascular risk factors in men: the role of gonadal steroids and sex hormone-binding globulin. Metabolism 2001;50(8):882-8.

[23] Van Pottelbergh I, Braeckman L, DeBacquer D, et al. Differential contribution of testosterone and estradiol in the determination of cholesterol and lipoprotein profile in healthy middle aged men. Atherosclerosis 2003;166(1):95-102.

[24] WU FCW. Androgens and coronary artery disease. Endocrine Reviews 2003;24:183-217.

[25] De Pergola G, Zamboni M, Sciaraffia M, et al. Body fat accumulation is possibly responsible for lower dehydroepiandrosterone circulating levels in premenopausal obese women. Int J Obes Relat Metab Disord 1996;20(12):1105-10.

[26] Berman DM, Rodrigues LM, Nicklas BJ, et al. Racial disparities in metabolism, central obesity, and sex hormone-binding globulin in postmenopausal women. J Clin Endocrinol Metab 2001;86(1):97-103.

[27] Bell RJ, Davison SL, Papalia MA, et al. Endogenous androgen levels and cardiovascular risk profile in women across the adult life span. Menopause 2007;14(4):630-8. 